\title{
Characteristics of leadership that influence clinical learning: A narrative review
}

Authors:

Rachel Walker

$\mathrm{MN}, \mathrm{BN}, \mathrm{BA}, \mathrm{RN}$

Lecturer, Clinical Coordinator, School of Nursing and Midwifery

Research Centre for Clinical \& Community Practice Innovation

Griffith Institute of Health and Medical Research

Griffith University, Nathan, 4111, Queensland Australia

r.walker@griffith.edu.au

Tel: (07) 37355247

Fax: (07) 37355431

Marie Cooke

PhD, MSPD, BAppSc, DAppSc (Nurs\&UnitMgt), RN

Professor, Deputy Head of School, School of Nursing and Midwifery,

Research Centre for Clinical \& Community Practice Innovation

Griffith Institute of Health and Medical Research

Griffith University, Nathan, 4111, Queensland Australia

Amanda Henderson

$\mathrm{PhD}, \mathrm{RN}$

Professor, Director of Nursing Education, Princess Alexandra Hospital,

Research Centre for Clinical \& Community Practice Innovation

Griffith Institute of Health and Medical Research

Griffith University, Nathan, 4111, Queensland Australia

Debra K. Creedy

PhD, M Ed, BA (Hons), RN

Professor, Head of Alice Lee Centre for Nursing Studies,

Yong Loo Lin School of Medicine at National University of Singapore

Research Centre for Clinical and Community Practice Innovation at Griffith University, Nathan, 4111, Queensland Australia 


\section{Abstract}

Leadership has been consistently implied in fostering clinical learning. However there is a lack of clarity about the form leadership should take. Limited quantitative research indicated a narrative approach to review literature from a broad perspective. A framework to guide the synthesis was developed to ensure a rigorous review process. Preliminary reading and review of papers using search terms nursing and leadership AND clinical learning AND learning culture narrowed the inclusion criteria to 245 papers published between 2000 and 2010. Given the diversity of the papers' focus, aim and context, a

refined screening process justified the inclusion of twenty-six papers in the review. A critical appraisal of these peer-reviewed quantitative, qualitative and commentary papers identified factors/elements integral to effective leadership. Across the literature leadership was discussed in relation to two broad themes: influence of leadership on organisational learning and development and; influence of leadership on undergraduate clinical education. The factors central to leadership emerged as transformative principles, the role of the nurse unit/ward manager, collaboration and relationship building and role-modelling. The review has raised some suggestions for future research aimed at examining the impact of a leadership capacity building intervention that supports clinical learning.

\section{Key words}

Nursing, leadership, clinical learning, learning culture, narrative review

\section{Introduction}

The influence of leadership in nursing, particularly its relationship to clinical learning is an underresearched phenomenon (Creedy \& Henderson, 2009; Davidson, Elliott, \& Daffurn, 2004). There are increasing calls for research examining the role and influence of nursing leadership on policy and decision making, (Cummings et al., 2010; Pearson \& Borbasi, 1996). There are also more generalised demands for the building of leadership capacity as a priority for the profession (Heath, 2002; Senate 
Community Affairs Committee, 2002). However there remains a clear gap in the literature examining the relationship between leadership and clinical learning and a lack of clarity about the factors that can advance the agenda to improve leadership capacity.

There is no one accepted definition that fully encompasses the complexity or development of attributes, actions or outcomes of the phenomenon of leadership (Langford \& Fitness, 2003). Contemporary influences such as the emergence of nursing as a profession, feminism, and commitment to evidencebased practice (Kerfoot, 2001), as well as population trends driving health care reforms and increased violence in the workplace, frame leadership in contemporary nursing (McMillan \& Conway, 2002). National reviews of nursing call for a move away from outdated task-focused leadership behaviours with recommendation for nurses to be provided with appropriate education and training to support them in leadership roles to enable their representation in management and decision-making (Heath, 2002; Senate Community Affairs Committee, 2002).

For the purpose of this review, leadership in nursing is defined as "a multifaceted process of identifying a goal or target, motivating other people to act, and providing support and motivation to achieve mutually negotiated goals" (Davidson, Elliott, \& Daly, 2006, p.182).

\section{Narrative Review}

The review represents the initial phase of enquiry for a quasi experimental comparison study with a prepost intervention strategy to improve clinical learning. The aim of this narrative review is to identify the contingent factors important in leadership that foster clinical learning to inform the focus/activities for future research. This method of synthesising research around the topic enables a comprehensive, "textual approach that provides an analysis of the relationships within and between studies and an 
overall assessment of the robustness of evidence" (Centre for Reviews and Dissemination, 2009, p. 48).

Narrative reviews have been criticised as biased due to their unclear search and analysis methods. However, narrative reviews which specifically synthesise research around a topic using a rigorous approach are credited as providing comprehensive and transparent perspectives (Collins \& Fauser, 2004; Green, Johnson, \& Adams, 2001). To ensure rigor, this narrative review has adapted the general framework for narrative synthesis described by the Centre for Reviews and Dissemination in (2009) to create a guiding framework. Refer to Figure 1.

This review explores relationships between leadership and clinical learning in nursing contexts. An initial scope of the literature using search terms nursing and leadership resulted in over 35000 database hits. Additional search terms clinical learning AND learning culture were included to refine the search strategy. Repetition of ranked papers indicated saturation at 245 hits. Electronic databases used included Medline, CINAHL, ProQuest, Ingenta, EBSCO, Cochrane, Google and Google Scholar. Secondary searches utilised journal article and text reference lists, and library catalogues from 1990 to the present time. Duplicate papers and dissertations were excluded as well as grey literature as it yields little relevant material for research purposes (Scott-Findlay \& Estabrooks, 2006).

As there were no papers that addressed the topic specifically, any published, quantitative, qualitative or commentary papers that could be linked to the review search terms were included. A preliminary reading and review of gathered papers revealed that the majority of articles devoted to leadership in nursing were published from 2000, thus the review narrowed the inclusion criteria to papers published between 2000 and 2010. Given the diversity of papers according to their focus, aim and context, a more refined selection process was undertaken. Papers were removed if they did not include direct reference 
Figure 1: Guiding framework for narrative synthesis

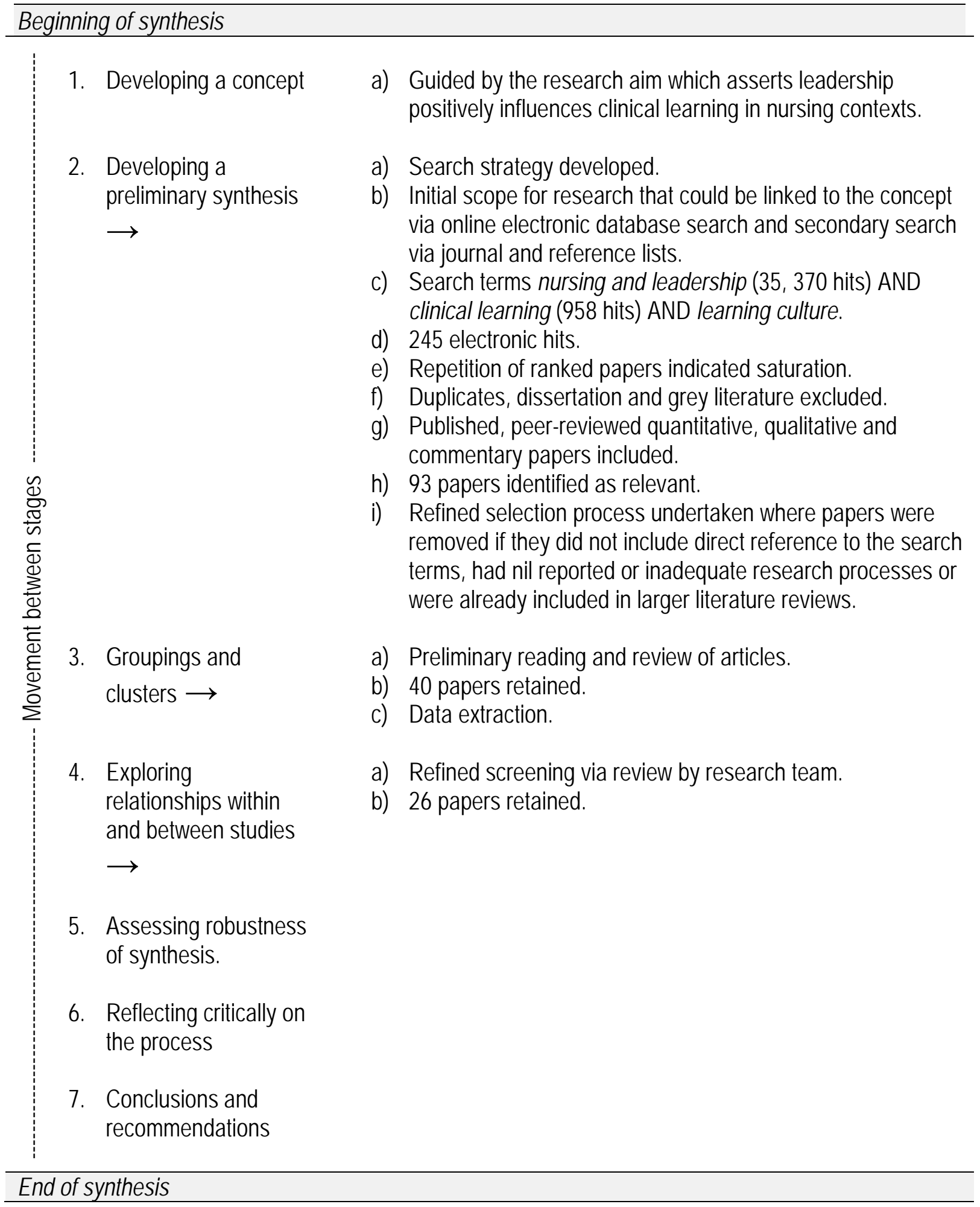

to the search terms, had nil reported or inadequate research processes or were already included in

larger literature reviews. Forty papers were reviewed to identify patterns, directions, similarities, 
differences and logical clusters of ideas. Those with identified relationships between leadership and clinical learning were then reviewed by the research team (comprising of me as the PhD candidate and my supervision team who are expert clinicians and researchers) to assess robustness of the synthesis, and critically reflect on the process. Following this refined screening process, twenty-six papers were included in the review.

The analysis of included papers involved a critical appraisal of content. After reading and re-reading the papers, aims and outcomes were compared to identify similarities. Tables of information from the studies were developed to aid synthesis which enabled content to be identified into key factors that assumed prominence in each paper (refer to Table 1) (Green et al., 2001). These factors identified two main themes in the literature where leadership influenced organisational development and learning and undergraduate clinical education (refer to Tables 2 and 3).

\section{The influence of leadership on organisational learning and development}

The successful development and implementation of learning initiatives appear to be dependent upon the leadership style and behaviour of the local leader (Callaghan, 2008; Duffield, Roche, O'BrienPallas, Catling-Paull, \& King, 2009). Effective leaders are credited as possessing the skills and knowledge to create and share an organisational vision and purpose to motivate staff, support collaboration and facilitate change (Bowles \& Bowles, 2000; Brady Germain \& Cummings, 2010; Henderson, 2010; Stapleton et al., 2007; Wallin, Rudberg, \& Gunningberg, 2005).

The results from a number of studies confirm an association between leadership behaviours and skills with successful organisational outcomes. Bowles \& Bowles' (2000) examination of the leadership styles of nurse leaders in Nursing Development Units (NDUs - centres of nursing excellence, innovation and leadership) found staff rated them more highly if they inspired a shared vision, promoted innovation, 
Table 1: Relationship of factors and elements to themes

\begin{tabular}{|c|c|c|}
\hline Themes & $\begin{array}{l}\text { Influence of leadership on organisational } \\
\text { learning and development }\end{array}$ & $\begin{array}{c}\text { Influence of leadership on undergraduate } \\
\text { clinical education }\end{array}$ \\
\hline $\begin{array}{l}\text { Transformative principles: empowerment, democracy, } \\
\text { vision and affiliation, motivation for change }\end{array}$ & $\begin{array}{l}\text { Alleyne \& Jumaa, 2007; Atsalos, O'Brien, \& Jackson, 2007; } \\
\text { Bowles \& Bowles, 2000; Brady Germain \& Cummings, } \\
\text { 2010; Callaghan, 2008; Casida \& Pinto-Zipp, 2008; } \\
\text { Cummings et al., 2010; Duffield, Roche, O'Brien-Pallas, } \\
\text { Catling-Paull, \& King, 2009; Henderson, 2010; Rowley, } \\
\text { 2006; Spirig et al., 2004; Stapleton et al., 2007; Tregunno et } \\
\text { al., 2009; Wallin, Rudberg, \& Gunningberg, 2005; Wong \& } \\
\text { Cummings, 2007; }\end{array}$ & $\begin{array}{l}\text { Allan, Smith, \& Lorentzon, 2008; Currie, Tolson, \& } \\
\text { Booth, 2007; Henderson et al., 2010; Livsey, 2009; } \\
\text { McGowan, 2006; O'Driscoll, Allan, \& Smith, 2010; } \\
\text { Thomas \& Burk, 2009; Zilembo \& Monterosso, } 2008\end{array}$ \\
\hline Role of nurse unit/ward manager & $\begin{array}{l}\text { Alleyne \& Jumaa, 2007; Atsalos et al., 2007; Bowles \& } \\
\text { Bowles, 2000; Callaghan, 2008; Casida \& Pinto-Zipp, 2008; } \\
\text { Cummings et al., 2010; Spirig et al., 2004; Stapleton et al., } \\
\text { 2007; Wong \& Cummings, } 2007\end{array}$ & $\begin{array}{l}\text { Currie et al., 2007; Henderson, 2010; Henderson et } \\
\text { al., 2010; McGowan, 2006; O'Driscoll et al., 2010; } \\
\text { Thomas \& Burk, } 2009\end{array}$ \\
\hline $\begin{array}{l}\text { Collaboration and relationship building: consultative, } \\
\text { inclusive, respectful, adaptable }\end{array}$ & $\begin{array}{l}\text { Alleyne \& Juuma, 2005; Atsalos, O'Brien, \& Jackson, 2007; } \\
\text { Bowles \& Bowles, 2000; Brady Germain \& Cummings, } \\
\text { 2010; Callaghan, 2008; Henderson, 2010; Rowley, 2006; } \\
\text { Spirig et al., 2004; Stapleton et al., 2007; Tregunno et al., } \\
\text { 2009; Wallin et al., } 2005\end{array}$ & $\begin{array}{l}\text { Hendricks, Cope, \& Harris, 2010; Schoenfelder \& } \\
\text { Valde, } 2009\end{array}$ \\
\hline
\end{tabular}


and recognised staff achievement. Using the Leadership Practices Inventory (LPI) based on a model of transformational leadership developed by Kouzes and Posner (1990) and telephone interviews, nursing behaviours of leaders in NDUs were compared with managers in conventional ward/unit settings via self and observer evaluation. Data gathered from a matched sample of 14 nurse leaders and 56 colleagues over a six-week period identified that NDU leaders were more self-aware with a propensity to provide practices of exemplary leadership particularly challenging the process, inspiring a shared vision and encouraging the heart (Bowles \& Bowles, 2000; Kouzes \& Posner, 1990).

Transformational leadership is repeatedly cited as the most effective leadership approach due to its emphasis on the development of supportive relationships (Bowles \& Bowles, 2000; Callaghan, 2008; Casida \& Pinto-Zipp, 2008; Spirig et al., 2004). Transformational relationships are credited as enabling staff to find meaning in their work, empowering them to communicate their ideas, participate collaboratively in a team and work towards effecting change (Alleyne \& Juuma, 2005; Rowley, 2006; Spirig et al., 2004; Stapleton et al., 2007; Wallin et al., 2005). The transference of supportive behaviours from leaders (such as open communication, sharing knowledge and ideas) to their staff also ensures the maintenance of leadership skills and capacity at all levels (Henderson, 2010).

Leadership styles that positively influence the work environment also shape its learning culture. In their systematic review of 53 published studies, Cummings et al (2010) found distinct patterns between leadership styles and outcomes for nurses and organisations. Content analysis was used to group outcomes into five categories (staff satisfaction with work, role and pay, staff relationships with work, staff health and well being, work environment factors and productivity and effectiveness). The review found people-focused relational leadership approaches (transformational, empowering, supportive and 
considerate) were associated with higher levels of job satisfaction while task-focused leadership (dissonant, instrumental, management by exception) were associated with lower job satisfaction. Within the category of work environment, relational leadership styles were linked to learning outcomes such as increased research utilisation, use of evidence-based practises and implementation of best practice guidelines (Cummings et al., 2010). Nurses cite lack of recognition and disempowerment as reasons for dissatisfaction in and abandonment of the profession. Staff who are recognised and supported by effective leaders are more likely to engage in learning (Cummings et al., 2010; Duffield et al., 2009).

Supportive leaders also yield better outcomes for patients, another key determinant in job satisfaction for nurses (Duffield et al., 2009). In their systematic review of 11 studies on nursing leadership and patient outcomes, Wong and Cummings (2007) found a strong relationship between positive leadership behaviours and improved patient safety, reduced patient complication and increased patient satisfaction (Wong \& Cummings, 2007). Fundamentally, patient safety is dependent on early detection and timely intervention by nurses. Tregunno et al., (2009) suggest patient safety is compromised when nurses do not possess the knowledge and skills to detect threats. To explore leadership characteristics that promoted a culture of safety, they conducted focus group interviews with critical care staff including nurse leaders $(n=51)$, nursing staff $(n=56)$ and physicians and allied health $(n=81)$. Findings revealed three themes: 1 . The leader is the "go-to"; 2 . The leader is "on the ball" and; 3 . Leaders keep the "ball rolling". The third theme focused on the importance of creating a learning context where leaders bring the team together, actively role-model knowledge acquisition via teaching and communication of rationale for practice and encourage critical thinking in staff (Tregunno et al., 2009).

Positive leadership behaviours that promote collaboration and effective communication are associated with knowledge acquisition and successful implementation of organisational initiatives (Alleyne \& Jumaa, 2007; Spirig et al., 2004; Wallin et al., 2005; Williamson, 2005). A UK study reported the 
successful implementation of a model of work-based learning for nursing leaders involved in practicebased councils from one Trust district in North West England. Practice-based councils were introduced in 1999 to specifically address issues regarding human resources, research and education, practice development and mental health. Membership of these practice-base councils is dominated by nursing with some representation from allied health, administrative and chaplaincy services. The action research intervention examined the effectiveness of a model of Shared Governance using a combination of facilitated reflection, coaching and mentorship to provide nursing staff participants $(n=$ 8) with the skills required to successfully implement the nursing-directed initiative. Over a 30 month period participants were interviewed and directly observed by researchers. Results suggest participant's leadership skills and knowledge significantly improved due to a guided program of effective communication, information sharing, reflection and evaluation (Williamson, 2005).

Similar results were reported in the successful implementation of an evidence-based leadership and management program for primary care nurses in the UK $(n=6)$. This program involved co-coaching, group clinical supervision, management and leadership interventions and other approaches aimed at improving patient services. Relationship behaviours introduced to nurse participants to promote collaboration or 'social capital', were successful in increasing confidence in initiating and implementing change. These behaviours included a 'bottom up' open thinking approach to solving problems, positive role modelling, recognising individual needs and aspirations, supporting and empowering staff at all levels to improve skills and capabilities, respecting individual contributions, and networking and information sharing to aid the achievement and celebration of the team/unit success (Alleyne \& Jumaa, 2007, p. 238).

The value of positive leadership behaviours in facilitating team collaboration is also evident in a program of action research that successfully improved advanced nursing expertise and practice in an 
HIV outpatients department in Switzerland (Spirig et al., 2004). An initial review of care delivery revealed practice was based mostly on tradition and experience, with a distinct division of labour between nurses and physicians. Nurse participants developed a new model of care which worked towards understanding the culture and organisation of the department, promoted interdisciplinary collaboration and clinical leadership and implemented and evaluated innovative nursing services for clients living with HIV. The development of a collaborative framework where nurses, physicians and allied health staff worked together was cited as a key component in the successful implementation of the Advanced Nursing Practice (ANP) Team. Individual responsibility and leadership within the team enabled nurses to develop specialist knowledge and practice to enhance the overall knowledge relevant to HIVIAIDS care.

The association between effective leaderships and collaboration is further examined in an investigation of the influence of external facilitation in the implementation of guidelines for Kangaroo Mother Care (KMC) in Swedish neonatal units (Wallin et al., 2005). The study was conducted concurrently with a randomised control trial to evaluate the impact of patient outcomes via the facilitation of KMC guideline implementation. The focus of the qualitative component was on staff perceptions of the change process. Results from the analysed focus group interviews of staff in the control $(n=9)$ and intervention sites $(n=11)$ found the presence of a supportive external facilitator in intervention wards positively predicted altered staff attitudes and/or change in practice regarding the implementation of the KMC guidelines. However the presence of an external facilitator appeared no more effective in one of the control wards where there was active involvement in the change process by the nurse manager. The nurse manager in the successful control ward was identified as pivotal in the successful adoption of the KMC guidelines illustrating a relationship between leadership, collaboration and change. 
The importance of collaboration in implementing development and learning programs is highlighted in a longitudinal Heideggerian hermeneutic enquiry into the unsuccessful introduction of Clinical Development Units (CDUs) in Australia (Atsalos, O'Brien, \& Jackson, 2007). Nurse leaders in 9 CDUs $(n=11)$ were regularly consulted about their efforts to develop their wards as centres of excellence over a four year period from 1998 to 2002. Results indicate CDU nurse leader's attempts were eroded due to a lack of leadership experience, waning support from higher management and limited involvement and understanding by nursing staff. There appears to have been an absence of strategies to involve and engage staff in the program with CDU leaders who acknowledged having limited discussion and consultation regarding the change process with unit nursing staff. Researchers propose this lack of collaboration as one of the reasons for program failure (Atsalos et al., 2007).

The factors identified as influencing organisational development and learning relate to effective transformative principles (empowerment, democracy, vision, affiliation and motivation for change), the role of the nurse unit/ward manager and collaboration and relationship building (consultative, inclusive, respectful and adaptable). Overall, a strong association between transformational leadership behaviours of nurse unit/ward managers and collaboration with staff emerged.

\section{The influence of leadership on undergraduate clinical learning}

Clinical learning in undergraduate nursing and the factors promoting or inhibiting its success has received intense research interest. Many of the studies reviewed identified the leadership role of nurse ward/unit manager as integral in developing the capacity of nursing staff to enhance the learning environment for students (Currie, Tolson, \& Booth, 2007; Henderson et al., 2010; McGowan, 2006; O'Driscoll, Allan, \& Smith, 2010; Thomas \& Burk, 2009). Described as the' gate-keeper', the nurse ward/unit manager is credited as having the power to help or hinder learners in their transference of learning to the clinical setting (Henderson, 2010; Thomas \& Burk, 2009). In clinical settings where 
Table 2: Influence of leadership on organisational learning and development

\begin{tabular}{|c|c|c|c|c|}
\hline $\begin{array}{l}\text { Author(s), year, title, } \\
\text { origin/context }\end{array}$ & Aim & Population, sample size, design & Findings and important considerations & Strengths (S) and limitations (L) \\
\hline $\begin{array}{l}\text { Alleyne and Jumaa, } 2007 \\
\text { Building the capacity for } \\
\text { evidence-based clinical nursing } \\
\text { leadership: the role of executive } \\
\text { co-coaching and group clinical } \\
\text { supervision for quality patient } \\
\text { services. } \\
\text { Executive co-coaching for } \\
\text { focused group clinical } \\
\text { supervision sessions involving } 6 \\
\text { x district nurses as co- } \\
\text { researchers and } 2 \times \text { professional } \\
\text { doctoral candidates as the main } \\
\text { researchers over a period of } 21 / 2 \\
\text { years } \\
\text { UK } \\
\text { Alleyne and Jumaa, } 2005 \\
\text { Leadership through group } \\
\text { clinical supervision } \\
\text { UK }\end{array}$ & $\begin{array}{l}\text { To facilitate primary } \\
\text { care nurses (District } \\
\text { Nurse Team Leaders) } \\
\text { to link management } \\
\text { and leadership } \\
\text { theories with clinical } \\
\text { practice and to } \\
\text { improve the quality of } \\
\text { the service provided } \\
\text { to their patients. } \\
\text { Specifically, to } \\
\text { identify, create and } \\
\text { evaluate effective } \\
\text { processes for } \\
\text { collaboration so that } \\
\text { nurses' capacity for } \\
\text { clinical decision- } \\
\text { making could be } \\
\text { improved. }\end{array}$ & $\begin{array}{l}\text { Qualitative - Multi-method } \\
\text { - Action research approach using } \\
\text { a collaborative enquiry within a } \\
\text { case study process. } \\
\text { - These sessions used the Clinical } \\
\text { Nursing Learning and Action } \\
\text { Process (CLINLAP) model } \\
\text { based on four main areas of } \\
\text { responsibility and accountability: } \\
\text { specific goals, explicit roles, } \\
\text { clear processes, open } \\
\text { relationships }\end{array}$ & $\begin{array}{l}\text { - Management and leadership interventions and approaches have } \\
\text { significantly influenced the participant's capacity to improve the quality of } \\
\text { services provided o their patients. } \\
\text { - Using various techniques, tools, methods and frameworks presented at } \\
\text { the sessions increased participant's confidence to perform. } \\
\text { - A structure approach like the CLINLAP model makes implementing } \\
\text { change more practical and manageable within a turbulent care } \\
\text { environment. The process of stakeholder mapping and management } \\
\text { made gaining consensus for change much easier. }\end{array}$ & $\begin{array}{l}\text { S- Multi-method data collection } \\
\text { approach to achieve multiple triangulation } \\
\mathrm{L}-\text { Some methods of data collection } \\
\text { (such as the questionnaires) not well } \\
\text { described. } \\
\mathrm{L}-\text { Small sample and focused on UK } \\
\text { context questioning reliability and } \\
\text { generalisability of the study. }\end{array}$ \\
\hline $\begin{array}{l}\text { Atsalos et al., } 2007 \\
\text { Against the odds: experiences of } \\
\text { nurse leaders in Clinical } \\
\text { Development Units (Nursing) in } \\
\text { Australia } \\
\text { Australia } \\
\text { Greenwood, J. } \\
1999 \\
\text { Clinical Development Units } \\
\text { (Nursing): the western Sydney } \\
\text { approach }\end{array}$ & $\begin{array}{l}\text { - To explore the } \\
\text { experiences, over } \\
\text { time, of nurse } \\
\text { leaders as they } \\
\text { attempted to } \\
\text { develop their units } \\
\text { into recognised } \\
\text { units of nursing } \\
\text { excellence }\end{array}$ & $\begin{array}{l}\text { - Longitudinal exploratory study } \\
\text { using Heideggerian hermeneutic } \\
\text { phenomenology } \\
\text { - } 14 \text { Clinical Development Unit } \\
\text { (CDU) nursing leaders from } 9 \\
\text { units participated in qualitative } \\
\text { guide' interviews } \\
\text { - A total of } 23 \text { interview over three } \\
\text { rounds from } 1998 \text { to } \\
\text { 2002.Transcribed texts were } \\
\text { thematically analysed using Non } \\
\text { numerical Unstructured Data } \\
\text { Indexing Searching and Theorizing } \\
\text { (NUD.IST) program } \\
\text { - Reflexive journal maintained }\end{array}$ & $\begin{array}{l}\text { 1. Reaching towards a new vision: leaders motivated and mindful of the } \\
\text { need to instigate change within the organisation } \\
\text { 2. Becoming invisible and forgotten: major obstacle was the lack of } \\
\text { understanding of the CDU philosophy in the organisation. } \\
\text { 3. Going it alone: as assurances failed, dissent increased and staff } \\
\text { originally involved dropped out leaders felt overwhelmingly isolated. } \\
\text { 4. Living with high expectations: uncertainty about meeting expectations, } \\
\text { frustration and disappointment } \\
\text { - Findings illustrate the difficulties involved in maintaining the commitment } \\
\text { of all levels if staff and management when attempting to introduce new } \\
\text { nursing projects. }\end{array}$ & $\begin{array}{l}\mathrm{L} \text { - Context focused (in a single health } \\
\text { service) thus limiting reliability and } \\
\text { generalisability of findings } \\
\mathrm{L}-\text { Small sample and questioning } \\
\text { reliability and generalisability of the study. } \\
\mathrm{S} \text { - Successfully identifies the obstacles } \\
\text { nursing leaders face in attempting to } \\
\text { make change within nursing. }\end{array}$ \\
\hline Bowles and Bowles, 2000 & To compare of the & - Comparative study & - Overall leadership provided by NDU leaders was higher than that of their & L- Possible Hawthorne Effect \\
\hline
\end{tabular}




\begin{tabular}{|c|c|c|c|c|}
\hline $\begin{array}{l}\text { A comparative study of } \\
\text { transformational leadership in } \\
\text { nursing development units and } \\
\text { conventional clinical settings } \\
\text { Nurse managers and leaders in } \\
\text { Nursing Development Units } \\
\text { (NDUs) and conventional clinical } \\
\text { settings across England } \\
\text { UK }\end{array}$ & $\begin{array}{l}\text { demonstrated } \\
\text { transformational } \\
\text { leadership behaviours } \\
\text { provided by nurse } \\
\text { managers and leaders } \\
\text { in NDUs }\end{array}$ & $\begin{array}{l}\text { - } 360 \text { degree feedback design: } \\
\text { 1. Self-evaluation } \\
\text { 2. Observer evaluation } \\
\text { 3. Comparison of the two } \\
\text { Data collected via: } \\
\text { - Leadership Practice Inventory } \\
\text { (LPI) Postal questionnaire. Only } 6 \\
\text { out } 30 \text { completed and returned. } \\
\text { - Telephone interviews of } \\
\text { participants over a six- week } \\
\text { period. Used the LPI instrument as } \\
\text { an interview schedule. - } 4 \text { x ward } \\
\text { managers were used with } \\
\text { success. } \\
\text { - Intervention - } 2 \times \text { matched } \\
\text { samples of } 70 \text { nurses recruited- } 14 \\
\text { nurse leaders and } 56 \text { of their day- } \\
\text { to-day colleagues. } 100 \% \text { response } \\
\text { rate }\end{array}$ & $\begin{array}{l}\text { non-NDU counterparts } \\
\text { - Self-evaluations were very similar between NDU and non-NDU leaders } \\
\text { - Congruence between self evaluations and observer evaluations for NDU } \\
\text { leaders who showed more transformational leadership behaviours } \\
\text { - Greater incongruence between self-evaluation and observer evaluations } \\
\text { in Non-NDU group }\end{array}$ & $\begin{array}{l}\mathrm{L}-\text { Small sample size and context } \\
\text { specific reducing the reliability and } \\
\text { generalisability of the results }\end{array}$ \\
\hline $\begin{array}{l}\text { Brady Germain and Cummings, } \\
2010 \\
\text { The influence of nursing } \\
\text { leadership on nurse } \\
\text { performance: a systematic } \\
\text { literature review } \\
\text { Canada }\end{array}$ & $\begin{array}{l}\text { To explore leadership } \\
\text { factors that influence } \\
\text { nurse performance } \\
\text { with emphasis on the } \\
\text { role that nursing } \\
\text { leadership behaviours } \\
\text { play in nurses' } \\
\text { perceptions of } \\
\text { performance } \\
\text { motivation. }\end{array}$ & $\begin{array}{l}\text { A review and content analysis of } 8 \\
\text { x peer reviewed research articles } \\
\text { (from } 88 \text { initially selected) that } \\
\text { examined the factors that nurses } \\
\text { perceived as influencing their } \\
\text { motivation and performance. } \\
\text { - Inclusion criteria included only } \\
\text { empirical research studies - either } \\
\text { qualitative or quantitative were } \\
\text { included. }\end{array}$ & $\begin{array}{l}\text { - Nurses perceptions of factors that influence their motivation and ability to } \\
\text { perform were grouped into five categories: } \\
\text { 1. Autonomy } \\
\text { 2. Work relationships } \\
\text { 3. Resource accessibility, } \\
4 . \quad \text { Individual nurse characteristics (hardiness, and ambiguity } \\
\text { tolerance) } \\
\text { 5. Leadership practices } \\
\text { - Nursing leadership behaviours were found to influence both nurses' } \\
\text { motivations directly and indirectly by the other factors. } \\
\text { - This suggests leadership may be improved by addressing autonomy, } \\
\text { relationships, and access to resources. }\end{array}$ & $\begin{array}{l}\text { L-A possible reporting bias of positive } \\
\text { findings in published studies. } \\
\mathrm{L}-\text { Variability in the conceptualisation and } \\
\text { measurement of factors of nurse } \\
\text { performance may limit validity and } \\
\text { generalisability of findings } \\
\mathrm{L}-\text { All } 8 \text { studies chosen used cross } \\
\text { sectional, correlational design which limit } \\
\text { their ability to estimate causation, are } \\
\text { prone to bias and have decreased } \\
\text { generalisability } \\
\mathrm{S}-\text { Positively identified a relationship } \\
\text { between leadership behaviours and } \\
\text { nurse performance. }\end{array}$ \\
\hline $\begin{array}{l}\text { Callaghan, } 2008 \\
\text { Advance nursing practice: an } \\
\text { idea whose time has come. } \\
\text { Ireland }\end{array}$ & $\begin{array}{l}\text { To critically analyse } \\
\text { the concept of } \\
\text { advanced nursing } \\
\text { practice and to } \\
\text { demonstrate and } \\
\text { appreciate of the } \\
\text { development of the }\end{array}$ & $\begin{array}{l}\text { Literature review that focuses on } \\
\text { expertise, transformational } \\
\text { leadership and collaboration using } \\
\text { the Sofarelli and Brown model of } \\
\text { leadership (1998) }\end{array}$ & $\begin{array}{l}\text { - Expertise: in search of the holy grail } \\
\text { The National Council for the Professional Development of Nursing and } \\
\text { Midwifery require ANPs to demonstrate exemplary critical thinking skills } \\
\text { in practical and theoretical knowledge. Using Sofarelli and Brown's } \\
\text { model, every leader must be a learner, thus expertise is an ongoing } \\
\text { process not an end-point. } \\
\text { - Transformational leadership: the challenge of the } 21^{\text {st }} \text { century }\end{array}$ & L-Commentary paper. \\
\hline
\end{tabular}




\begin{tabular}{|c|c|c|c|c|}
\hline & $\begin{array}{l}\text { role of the advanced } \\
\text { nurse practitioner } \\
\text { (ANP) in the Irish } \\
\text { context }\end{array}$ & & $\begin{array}{l}\text { The ANP characteristics of the Scope of Practice for Nursing and } \\
\text { Midwifery are synonymous with a transformational style of leadership with } \\
\text { an emphasis on innovation, vision and change. Require the development } \\
\text { and support of supportive bureaucratic structures. } \\
\text { - Collaboration: the synergistic way forward } \\
\text { ANPs should recognise that collaboration with other nurses, health care } \\
\text { works in the delivery of patient care is essential. This may require the } \\
\text { ANP enable to members of the multi-disciplinary team via the } \\
\text { establishment of teams to support participation and empowerment and to } \\
\text { recognise and celebrate participation and accomplishments. }\end{array}$ & \\
\hline $\begin{array}{l}\text { Cummings et al., } 2010 \\
\text { Leadership styles and outcome } \\
\text { patterns for the nursing } \\
\text { workforce and work } \\
\text { environment: A systematic } \\
\text { review } \\
\text { Canada }\end{array}$ & $\begin{array}{l}\text { A systematic review of } \\
\text { leadership styles and } \\
\text { outcome patterns for } \\
\text { the nursing workforce } \\
\text { and work } \\
\text { environments. }\end{array}$ & $\begin{array}{l}34,664 \text { titles and abstracts screened } \\
\text { resulting in } 53 \text { included quantitative } \\
\text { studies }\end{array}$ & $\begin{array}{c}\text { - Using content analysis } 64 \text { outcomes were grouped into five categories } \\
\text { 1. Staff satisfaction with work role and pay } \\
\text { 2. } \quad \text { Staff relationships with work } \\
\text { 3. Staff health and well-being } \\
\text { 4. } \text { Work environment factors } \\
\text { 5. Productivity and effectiveness } \\
\text { - Distinctive patterns emerged, e.g., leadership styles that focused on } \\
\text { people and relationships were associated with higher nursing job } \\
\text { satisfaction whereas leadership styles that focused on tasks were } \\
\text { associated with lower nurse job satisfaction }\end{array}$ & $\begin{array}{l}\text { S- Systematic review of quantitative } \\
\text { studies } \\
\text { L- Potential of reporting bias by } \\
\text { including only published quantitative } \\
\text { studies. } \\
\text { L-Variability in the conceptualisation } \\
\text { and measurement of leadership possible } \\
\text { limiting the validity and generalisability of } \\
\text { findings. } \\
\text { L- No RCTs found and limited control of } \\
\text { extraneous variables }\end{array}$ \\
\hline $\begin{array}{l}\text { Davidson et al., } 2006 \\
\text { Clinical leadership in } \\
\text { contemporary clinical practice: } \\
\text { implications for nursing in } \\
\text { Australia. } \\
\text { Australia }\end{array}$ & $\begin{array}{l}\text { To define and } \\
\text { describe clinical } \\
\text { leadership and } \\
\text { identify the facilitators } \\
\text { and barriers to clinical } \\
\text { leadership. To also } \\
\text { describe strategies to } \\
\text { develop clinical } \\
\text { leaders in Australia. }\end{array}$ & $\begin{array}{l}\text { Literature review in Australian health } \\
\text { context. }\end{array}$ & $\begin{array}{l}\text { - Leadership defined as "a multifaceted process of identifying a goal or } \\
\text { target, motivating other people to act, and providing support and } \\
\text { motivation to achieve mutually negotiated."(p.182) } \\
\text { - Issues discussed include: facilitators to clinical leadership, nurse } \\
\text { coordinated clinical management strategies, collaboration between acute, } \\
\text { sub-acute and community settings, barriers to clinical leadership, } \\
\text { increased workload and patient nurse ratios, increased acuity of patients } \\
\text { - Strategies to develop clinical leaders in Australia: development of Nurse } \\
\text { Practitioner roles, introduction of the Clinical Professor in Nursing, } \\
\text { professional societies, mentorship and clinical supervision programs, } \\
\text { clinical and professional doctorates, designated paths of career } \\
\text { progression, intra- and interprofessional collaboration, collaboration } \\
\text { between academic and clinical areas, development of leadership skills (in } \\
\text { the affective domain) as well as research and knowledge }\end{array}$ & L-Commentary paper \\
\hline $\begin{array}{l}\text { Duffield et al., } 2009 \\
\text { Staff satisfaction and retention } \\
\text { and the role of the Nursing Unit } \\
\text { Manager } \\
\text { Nursing staff in public sector }\end{array}$ & $\begin{array}{l}\text { Discusses factors } \\
\text { impacting on nurses' } \\
\text { job satisfaction with } \\
\text { nursing and intention } \\
\text { to leave. }\end{array}$ & $\begin{array}{l}\text { - Staffing and patient data were } \\
\text { collected on } 80 \text { medical and } \\
\text { surgical units during 2004/5 } \\
\text { including individual nurse data (via } \\
\text { the Nurse Survey including the } \\
\text { Nursing Work Index-Revised), }\end{array}$ & $\begin{array}{l}\text { Statistically significant predictors of job satisfaction } \\
\text { - Nursing intending to remain in their job were more likely to be: satisfied, } \\
\text { older, experiencing good leadership, have allied health support } \\
\text { - Work environment factors such as: autonomy, control over practice, } \\
\text { nursing leadership on the wards }\end{array}$ & $\begin{array}{l}\text { L - Sample size vague } \\
\mathrm{S} \text { - The role of the NUM is important in } \\
\text { staff retention as they influence job } \\
\text { satisfaction, and positive work } \\
\text { environments }\end{array}$ \\
\hline
\end{tabular}




\begin{tabular}{|c|c|c|c|c|}
\hline $\begin{array}{l}\text { hospitals in New South Wales. } \\
\text { Australia }\end{array}$ & & $\begin{array}{l}\text { staffing data, patient } \\
\text { characteristics, workload data, } \\
\text { ward characteristics and adverse } \\
\text { event patient data. }\end{array}$ & & \\
\hline $\begin{array}{l}\text { Henderson, } 2010 \\
\text { Leadership in clinical education } \\
\text { - Embedding learning in } \\
\text { everyday practice } \\
\text { Australia }\end{array}$ & Editorial & Editorial & $\begin{array}{l}\text { - 'Real' practice learning experiences are invaluable for nurses prior to } \\
\text { registration, upon graduate and in the development of specialist skills. } \\
\text { - RNs need to teach, demonstrate and practice positive behaviours. } \\
\text { - Leadership essential - ward managers and shift team leaders credited as } \\
\text { being the gate-keepers in the development of positive learning } \\
\text { environments. } \\
\text { - Leadership behaviours including open communication, sharing } \\
\text { knowledge and ideas can create a chain of positive influence from senior } \\
\text { nursing leaders to novice nurses, including students. } \\
\text { - The articulation of specific leadership activities for adoption by staff at all } \\
\text { levels within the organisation is crucial for the development of the } \\
\text { learning organisation. } \\
\text { - Collaboration between academic and industry identifies a range of } \\
\text { activities to nurture learning }\end{array}$ & L-Editorial \\
\hline $\begin{array}{l}\text { Rowley, S. } \\
2006 \\
\text { The journey of a teaching } \\
\text { hospital to become a learning } \\
\text { organisation } \\
\text { Australia }\end{array}$ & $\begin{array}{l}\text { The aim was to } \\
\text { improve the } \\
\text { commitment and } \\
\text { satisfaction of its staff }\end{array}$ & $\begin{array}{l}\text { - Case study documenting the } \\
\text { progress made by the Mercy } \\
\text { Hospital in Melbourne (an acute } \\
\text { tertiary facility) in moving away } \\
\text { from a culture of blame using } \\
\text { change management principles } \\
\text { aligned with the concept of the } \\
\text { learning organisation } \\
\text { - Pre- post staff climate survey }\end{array}$ & $\begin{array}{l}\text { - The use if a more open and participatory style of management together } \\
\text { with a focus on enhancing and recognising performance can assist health } \\
\text { services to improve staff satisfaction and commitment } \\
\text { - Acknowledges the exploratory nature of the process: }\end{array}$ & $\begin{array}{l}\text { L- Context based thus reducing the } \\
\text { validity and generalisability of the results } \\
\text { L- Survey not identified } \\
\text { L - Survey sample not identified }\end{array}$ \\
\hline $\begin{array}{l}\text { Spirig et al., } 2004 \\
\text { The Advanced Nursing Practice } \\
\text { Team as a model for HIVIAIDS } \\
\text { caregiving in Switzerland } \\
\text { HIV Outpatient Department at } \\
\text { the University Hospital in Basel } \\
\text { Switzerland }\end{array}$ & $\begin{array}{l}\text { To offer advanced } \\
\text { nursing care for } \\
\text { people living with HIV } \\
\text { via a program of } \\
\text { learning, } \\
\text { organisational and } \\
\text { cultural change, } \\
\text { leadership } \\
\text { development and } \\
\text { interdisciplinary } \\
\text { collaboration. }\end{array}$ & $\begin{array}{l}\text { - Participatory action research used } \\
\text { in a HIV outpatient department. } \\
\text { - Emancipatory and transformational } \\
\text { leadership processes (reflection, } \\
\text { inclusion, empowerment, } \\
\text { development of a shared vision) } \\
\text { used to bring new knowledge to } \\
\text { practice. }\end{array}$ & $\begin{array}{l}\text { - Patient centeredness: essential that all services place patients and } \\
\text { families at the centre of care } \\
\text { - Learning to work professionally: nurses continually integrate new } \\
\text { knowledge into practice via reflection and self-direction } \\
\text { - Shaping the work environment: development of a regular forum } \\
\text { schedule to enable group reflection /discussion re. knowledge, } \\
\text { structures, routines. } \\
\text { - Clinical leadership: nurses responsible for increasing clinical expertise } \\
\text { relevant to HIVIAIDS and share this with nursing colleagues } \\
\text { - Interdisciplinary collaboration: development of a regular forum schedule } \\
\text { to enable reflection /discussion re. knowledge, structures, routines } \\
\text { - Development and evaluation of new nursing services: such as an } \\
\text { evidence assessment guide for patient assessment, a medication } \\
\text { management model, a symptom management model, health promotion }\end{array}$ & $\begin{array}{l}\mathrm{L}-\text { Result seems anecdotal thus limiting } \\
\text { reliability and generalisability of findings } \\
\mathrm{L}-\text { No presentation of data re. change in } \\
\text { clinical expertise of individual nurses, } \\
\text { collaboration or improved client outcomes } \\
\mathrm{L} \text { - Sample size not identified } \\
\mathrm{S} \text { - Anecdotal evidence suggests } \\
\text { improvement in nurses' clinical expertise, } \\
\text { work environment, collaboration and } \\
\text { patient services, }\end{array}$ \\
\hline
\end{tabular}




\begin{tabular}{|c|c|c|c|c|}
\hline & & & $\begin{array}{l}\text { and prevention programs and family assessment and intervention } \\
\text { program }\end{array}$ & \\
\hline $\begin{array}{l}\text { Stapleton et al., } 2007 \\
\text { Boosting morale and improving } \\
\text { performance in the nursing } \\
\text { setting. } \\
\text { Australia }\end{array}$ & $\begin{array}{l}\text { Drawing on } \\
\text { educational, } \\
\text { organisational and } \\
\text { psychological } \\
\text { literature, the paper } \\
\text { argues the ability to } \\
\text { inspire morale in staff } \\
\text { is a fundamental } \\
\text { indicator of sound } \\
\text { leadership and } \\
\text { managerial } \\
\text { characteristics. }\end{array}$ & Literature Review & $\begin{array}{l}\text { Guidelines for RNs to improve morale: } \\
\text { - Role preparation for ward managers via coaching } \\
\text { - Understanding motivation through reflection } \\
\text { - Fostering motivation: develop the drive to achieve via opportunities; } \\
\text { ensure opportunities are achievable; help RNs find personal value and } \\
\text { meaning in their work, create work environment that is open, positive and } \\
\text { inclusive; encourage good communication and practice; encourage RNs } \\
\text { to critique their own work } \\
\text { - Invest in relationships }\end{array}$ & L-Commentary paper \\
\hline $\begin{array}{l}\text { Tregunno et al., } 2009 \\
\text { On the Ball: Leadership for } \\
\text { Patient Safety and Learning in } \\
\text { Critical Care } \\
\text { Focus groups of frontline } \\
\text { providers and managers in six } \\
\text { teaching hospitals in the } \\
\text { province of Ontario. } \\
\text { Canada }\end{array}$ & $\begin{array}{l}\text { To explore leadership } \\
\text { for patient safety in } \\
\text { critical care and } \\
\text { identify opportunities } \\
\text { to improved } \\
\text { leadership that } \\
\text { promotes patient } \\
\text { safety. }\end{array}$ & $\begin{array}{l}\text { - Thirty-one focus groups with } 188 \\
\text { participants from front-line multi- } \\
\text { disciplinary providers and } \\
\text { managers over a } 9 \text { month period } \\
\text { to gain insight into leadership that } \\
\text { promotes patient safety and } \\
\text { learning. } \\
\text { - Convenience sample }\end{array}$ & $\begin{array}{l}\text { Three key themes emerged: } \\
\text { 1. The leader is the "Go to" who can manage any situation, is well informed } \\
\text { and knows what is happening on the unit at all times: extensive knowledge } \\
\text { and experience, leads by example, respected by staff, approachable, } \\
\text { reliable, history of providing safe care } \\
\text { 2. The leader is "on the ball": has a global perspective, is prepared to get } \\
\text { their hands dirty, flags potential risks and is proactive in prevention } \\
\text { 3. Leaders keep the "ball rolling" to keep patients safe: brings the team } \\
\text { together, advocates for patients and junior nurses, willingly teaches and } \\
\text { communicates, is respectful, non-judgemental and encourages critical } \\
\text { thinking }\end{array}$ & $\begin{array}{l}\text { L - Reliability and generalisability of } \\
\text { findings limited - all data collected from } \\
\text { critical care units in tertiary acute care } \\
\text { hospitals } \\
\text { S - Leadership for patient safety resides } \\
\text { primarily with nurses providing direct } \\
\text { patient care. }\end{array}$ \\
\hline $\begin{array}{l}\text { Wallin et al., } 2005 \\
\text { Staff experiences in } \\
\text { implementing guidelines for } \\
\text { Kangaroo Mother Care - a } \\
\text { qualitative study } \\
\text { Four neonatal units in four } \\
\text { county hospitals in central } \\
\text { Sweden }\end{array}$ & $\begin{array}{l}\text { To investigate staff } \\
\text { experiences in } \\
\text { implementing } \\
\text { guidelines for } \\
\text { Kangaroo Mother } \\
\text { Care in neonatal care. } \\
\text { Part of a randomized } \\
\text { controlled trial to } \\
\text { assess the impact of } \\
\text { external facilitation. }\end{array}$ & $\begin{array}{l}\text { - } 8 \mathrm{x} \text { focus group interviews were } \\
\text { held at } 4 \text { neonatal units at } 4 \mathrm{x} \\
\text { county hospitals in Sweden }-2 \mathrm{x} \\
\text { intervention and } 2 \mathrm{x} \text { control units } \\
\text { (ie., } 2 \mathrm{x} \text { focus groups interviews } \\
\text { held at each site). } \\
\text { - A total of } 45 \text { staff participated and } \\
\text { consisted of RNs, practical nurses. } \\
\text { Convenience sample }\end{array}$ & $\begin{array}{l}\text { - Results indicate that the facilitated intervention wards promoted } \\
\text { implementation activities and was highly appreciated by the change } \\
\text { teams. } \\
\text { - Reviewing the development of events at one of the control units, it is } \\
\text { evident that existing organisational values and clear leadership by the } \\
\text { nurse manager seemed to have worked as effectively as the supported } \\
\text { intervention wards. }\end{array}$ & $\begin{array}{l}\text { S-Study suggests that learning and } \\
\text { behaviour change seem to be a social } \\
\text { phenomenon that is greatly influenced by } \\
\text { strong leadership, interaction and } \\
\text { support. }\end{array}$ \\
\hline $\begin{array}{l}\text { Williamson, T. } \\
2005 \\
\text { Work-based learning: a } \\
\text { leadership development } \\
\text { example from an action research } \\
\text { study of shared governance } \\
\text { implementation }\end{array}$ & $\begin{array}{l}\text { - To evaluate and } \\
\text { strengthen the } \\
\text { implementation of } \\
\text { shared governance } \\
\text { Identify factors that } \\
\text { act as aids or } \\
\text { barriers to effective }\end{array}$ & $\begin{array}{l}\text { - A qualitative action research } \\
\text { approach where the researcher } \\
\text { worked with participants to } \\
\text { integrate work-based learning over } \\
\text { a } 30 \text {-month period. } \\
\text { - } 200+\text { hours of participant- } \\
\text { observations and } 8 \text { x face-to-face }\end{array}$ & $\begin{array}{l}\text { - Leadership skills and knowledge were significantly enhanced with the } \\
\text { implementation of shared governance. } \\
\text { - Work-based learning proved a valuable mechanism to identify existing } \\
\text { skills and development needs, explore possible solutions to work place } \\
\text { issues and facilitate context-specific organisational learning. }\end{array}$ & $\begin{array}{l}\text { L - Focused on the UK context only } \\
\text { questioning reliability and generalisability } \\
\text { of the literature study. } \\
\text { L - Small sample size } \\
\text { S - Regular participant checking of } \\
\text { formative findings }\end{array}$ \\
\hline
\end{tabular}




\begin{tabular}{|c|c|c|c|c|}
\hline $\begin{array}{l}\text { Work-based learning for nurse } \\
\text { leaders involved in practice- } \\
\text { based councils from one Trust } \\
\text { district in North West England } \\
\text { UK }\end{array}$ & $\begin{array}{l}\text { decision making by } \\
\text { clinical leaders. }\end{array}$ & $\begin{array}{l}\text { interviews were undertaken with } \\
\text { shared governance members and } \\
2 \mathrm{x} \text { focus group interviews were } \\
\text { conducted with the Human } \\
\text { Resources and Mental Health } \\
\text { Councils }\end{array}$ & & \\
\hline $\begin{array}{l}\text { Wong and Cummings, } 2007 \\
\text { The relationship between } \\
\text { nursing leadership and patient } \\
\text { outcomes } \\
\text { Canada }\end{array}$ & $\begin{array}{l}\text { To describe findings } \\
\text { of a systematic review } \\
\text { of studies that } \\
\text { examine the } \\
\text { relationship between } \\
\text { nursing leadership } \\
\text { and patient outcomes. }\end{array}$ & $\begin{array}{l}\text { - Published English language } \\
\text { research articles that examined } \\
\text { formal nursing leadership and } \\
\text { patient outcomes selected from } \\
\text { computerised database and } \\
\text { manual searches. } \\
\text { - } 7 \text { x quantitative research articles } \\
\text { met criteria }\end{array}$ & $\begin{array}{l}\text { - Evidence of significant associations between positive leadership } \\
\text { behaviours, styles or practices and: increased patient safety, increase } \\
\text { patient satisfaction; decreased patient complications. } \\
\text { - Inconclusive findings related to leadership and patient mortality rates. } \\
\text { - } 4 \text { x studies hypothesised that positive leadership behaviours } \\
\text { (transformative, empowering, supportive etc) may be associated with } \\
\text { outcomes via the facilitation of more effective teamwork. } \\
\text { - Nurse satisfaction was correlated with both positive leadership and } \\
\text { patient satisfaction in one study } \\
\text { - Findings suggest need for development of transformational nursing } \\
\text { leadership is an important organisational strategy to improve patient } \\
\text { outcomes. }\end{array}$ & $\begin{array}{l}\mathrm{L}-\text { Few studies reporting a relationship } \\
\text { between leadership and patient } \\
\text { outcomes. } \\
\mathrm{L}-\text { The variety of measures, samples } \\
\text { and procedures limit the consolidation of } \\
\text { findings } \\
\mathrm{L} \text { - Reporting bias possible as only } \\
\text { English language studies included and } \\
\text { published studies tend to over report } \\
\text { positive findings. } \\
\mathrm{S}-\text { Evidence to support a positive } \\
\text { relationship between transformational } \\
\text { leadership and improved patient } \\
\text { outcomes. }\end{array}$ \\
\hline
\end{tabular}

Table 3: Influence of leadership on undergraduate clinical education

\begin{tabular}{|c|c|c|c|c|}
\hline Author(s), year, title, origin & Aim & Population, sample size, design & Findings and important considerations & Strengths (S) and limitations (L) \\
\hline $\begin{array}{l}\text { Allan et al., } 2008 \\
\text { Leadership for nursing: a literature } \\
\text { study for leadership for learning in } \\
\text { clinical practice. } \\
\text { UK }\end{array}$ & $\begin{array}{l}\text { To report a } \\
\text { literature study of } \\
\text { leadership for } \\
\text { learning in clinical } \\
\text { practice in the } \\
\text { UK. }\end{array}$ & $\begin{array}{l}\text { Paper divided into two parts: } \\
\text { literature concerning the structural } \\
\text { and policy changes which have } \\
\text { affected the nature of leadership for } \\
\text { learning and; literature on learning } \\
\text { on professional nursing practice. } \\
\text { Interspersed within these } \\
\text { discussions are extracts from } \\
\text { stakeholder interviews }\end{array}$ & $\begin{array}{l}\text { Issues } \\
\text { - Changes in clinical leadership: traditional nurse role-models who had an } \\
\text { education agenda are being replaced with nurse specialists with } \\
\text { workforce agenda. } \\
\text { - Evaluation of the move to higher education in the 1990s: university based } \\
\text { lecturers are increasingly distant from clinical practice. } \\
\text { - The nature if professional learning in nursing: workforce changes have } \\
\text { restricted the opportunities for trained nurses to role model caring } \\
\text { activities for student nurses. } \\
\text { - Learning experiences in practice: committed and supported mentors } \\
\text { remain the key leaders for learning in current nursing curricula. }\end{array}$ & $\begin{array}{l}\text { L - Focused on the UK context only } \\
\text { questioning reliability and generalisability } \\
\text { of the literature study. }\end{array}$ \\
\hline
\end{tabular}




\begin{tabular}{|c|c|c|c|c|}
\hline $\begin{array}{l}\text { Currie et al., } 2007 \\
\text { Helping or hindering: the role of } \\
\text { nurse managers in the transfer of } \\
\text { practice development learning. } \\
\text { Graduate specialists graduated from } \\
\text { a Bachelor of Science program in } \\
\text { Scotland and employed in seven } \\
\text { health boards across Scotland } \\
\text { UK }\end{array}$ & $\begin{array}{l}\text { Report from study } \\
\text { outlining how } \\
\text { graduates from a } \\
\text { specialist nursing } \\
\text { program engage } \\
\text { in practice } \\
\text { development } \\
\text { during their } \\
\text { subsequent } \\
\text { careers }\end{array}$ & $\begin{array}{l}\text { - Study applied a modified Glaserian } \\
\text { approach to grounded theory. } \\
\text { - A preliminary descriptive survey } \\
\text { was posted to all graduates from } \\
\text { the specialist nursing program with } \\
\text { a response rate of } 45 \%(n=102) \text {. } \\
\text { - From these respondents } \\
\text { theoretical sampling decisions } \\
\text { directed the selection of } 20 \\
\text { participants for interview, enabling } \\
\text { data saturation over an } 18 \text { month } \\
\text { period. } \\
\text { - Interview participants chosen via } \\
\text { sampling criteria were } \\
\text { characterised by level of } \\
\text { leadership from promoted active } \\
\text { leaders to inactive participants, as } \\
\text { well as a group of randomly } \\
\text { selected participants. }\end{array}$ & $\begin{array}{l}\text { Results: } \\
\text { - The importance of context: being enabled or being blocked based on: } \\
\text { position in the hierarchy; supportive managers or peers, policy } \\
\text { imperatives and; organisational, clinical governance and personal } \\
\text { planning processes. } \\
\text { - The line manager is identified as gate-keeper in either helping or } \\
\text { hindering graduate specialist practitioners to transfer their learning to the } \\
\text { clinical setting. } \\
\text { Recommendations: } \\
\text { - The introduction of succession planning or the selection and mentoring of } \\
\text { individuals with the potential to become specialist nurses. } \\
\text { - Regular discussions between managers and students to review progress. } \\
\text { - Linking of personal development to professional development, that is an } \\
\text { expectation that specialist nurse graduates will take a lead role in practice } \\
\text { development } \\
\text { - Service managers should demonstration commitment via identification } \\
\text { and management of constraints such as horizontal violence. }\end{array}$ & $\begin{array}{l}\mathrm{L}-\text { Response rate of }<70 \% \text { may be } \\
\text { considered low } \\
\mathrm{L}-\text { Internal consistency of survey not } \\
\text { indicated thus limiting its validity and } \\
\text { reliability. } \\
\mathrm{S}-\text { Bi-data collection method } \\
\text { strengthened the study. }\end{array}$ \\
\hline $\begin{array}{l}\text { Henderson, } 2010 \\
\text { Leadership in clinical education - } \\
\text { Embedding learning in everyday } \\
\text { practice } \\
\text { Australia }\end{array}$ & Editorial & Editorial & $\begin{array}{l}\text { - 'Real' practice learning experiences are invaluable for nurses prior to } \\
\text { registration, upon graduate and in the development of specialist skills. } \\
\text { - RNs need to teach, demonstrate and practice positive behaviours. } \\
\text { - Leadership essential - ward managers and shift team leaders credited as } \\
\text { being the gate-keepers in the development of positive learning } \\
\text { environments. } \\
\text { - Leadership behaviours including open communication, sharing } \\
\text { knowledge and ideas can create a chain of positive influence from senior } \\
\text { nursing leaders to novice nurses, including students. } \\
\text { - The articulation of specific leadership activities for adoption by staff at all } \\
\text { levels within the organisation is crucial for the development of the } \\
\text { learning organisation. } \\
\text { - Collaboration between academic and industry identifies a range of } \\
\text { activities to nurture learning }\end{array}$ & $\mathrm{L}-$ Editorial \\
\hline $\begin{array}{l}\text { Henderson et al., } 2010 \\
\text { Creating supportive clinical learning } \\
\text { environments: an intervention study } \\
\text { A large tertiary hospital, South East } \\
\text { Queensland. } \\
\text { Australia }\end{array}$ & $\begin{array}{l}\text { To assess the } \\
\text { impact of an } \\
\text { intervention } \\
\text { aimed at building } \\
\text { capacity of RNs } \\
\text { to enhance the } \\
\text { learning } \\
\text { environments for }\end{array}$ & $\begin{array}{l}\text { - First, second and third year } \\
\text { nursing students }(n=62) \text { who } \\
\text { undertook their clinical placement } \\
\text { in two surgical wards before, } \\
\text { during and after a six-week } \\
\text { capacity building intervention for } \\
\text { RNs. } \\
\text { - A quasi-experimental design using }\end{array}$ & $\begin{array}{l}\text { - Students who undertook their clinical placement during the intervention } \\
\text { period rated the psycho-social clinical learning environment significantly } \\
\text { higher than students who undertook their practicum outside the } \\
\text { intervention period. } \\
\text { - Mean scores }(p-\text { value) for during and outside intervention periods: } \\
\text { - satisfaction }<0.001 \text {, personalisation }<0.001 \text {, involvement } 0.001 \text {, } \\
\text { innovation } 0.001 \text {, individualisation } 0.015 \text {, task Orientation } 0.048 \\
\text { - Results indicate sustainability over a period of time is problematic }\end{array}$ & $\begin{array}{l}\text { L - Small sample size } \\
\text { L - Context specific questioning reliability } \\
\text { and generalisability in other contexts } \\
\mathrm{S} \text { - The leadership role of the NUM is cited } \\
\text { as integral in the development of capacity } \\
\text { building of staff. }\end{array}$ \\
\hline
\end{tabular}




\begin{tabular}{|c|c|c|c|c|}
\hline & $\begin{array}{l}\text { undergraduate } \\
\text { nursing students }\end{array}$ & $\begin{array}{l}\text { data from the Clinical Learning } \\
\text { Environment Inventory (CLEI) }\end{array}$ & $\begin{array}{l}\text { - The leadership role of the Nurse Unit Manager is integral in the } \\
\text { development of capacity building of staff }\end{array}$ & \\
\hline $\begin{array}{l}\text { Hendricks et al., } 2010 \\
\text { A leadership program in an } \\
\text { undergraduate nursing course in } \\
\text { Western Australia: Building leaders } \\
\text { in our midst } \\
\text { Edith Cowan University. } \\
\text { Australia }\end{array}$ & $\begin{array}{l}\text { To develop } \\
\text { students } \\
\text { leadership to } \\
\text { prepare them for } \\
\text { the dynamic } \\
\text { context of health } \\
\text { care. }\end{array}$ & $\begin{array}{l}\text { - } 9 \text { x } 4 \text { th semester nursing students } \\
\text { (in a three-year program) } \\
\text { Participant numbers limited to } \\
\text { equal selected leader mentors. } \\
\text { - Intervention: Program consisted of } \\
3 \text { components: } \\
\text { 1. Leadership knowledge } \\
2 . \quad \text { Leadership skills } \\
\text { 3. Leadership in action } \\
\text { - Students worked in a leadership } \\
\text { capacity with a leader mentor in } \\
\text { health care and were required to } \\
\text { complete a minimum of } 30 \mathrm{~h} \text { of } \\
\text { work on an assigned project. } \\
\text { - Pre and post survey for } \\
\text { participating students }\end{array}$ & $\begin{array}{l}\text { - Statically significant change in key leadership skills and behaviour on } \\
\text { completion of the program (Wilcoxon Signed Rank test } p>0.05 \text { for each } \\
13 \text { leadership attributes with scores significantly higher on the post } \\
\text { survey. } \\
\text { - Findings demonstrated that participants increased their ability to } \\
\text { influence, persuade and motivate others, to effectively communicate } 1 \text {, to } \\
\text { team build and work collaboratively, to develop problem solving and } \\
\text { personal skills to overcome obstacles and to serve as agents for positive } \\
\text { change }\end{array}$ & $\begin{array}{l}\text { L- Small convenience sample thus limited } \\
\text { reliability and generalisability of findings. } \\
\text { L- Possible Hawthorne Effect due to } \\
\text { elective nature of course. }\end{array}$ \\
\hline $\begin{array}{l}\text { Livsey, } 2009 \\
\text { Structural Empowerment and } \\
\text { Professional Nursing Practice } \\
\text { Behaviours of Baccalaureate Nursing } \\
\text { Students in Clinical Learning } \\
\text { Environments } \\
\text { Random recruitment of students from } \\
\text { the National Nursing Students } \\
\text { Association enrolled in } \\
\text { baccalaureate nursing programs } \\
\text { from } 16 \text { states. } \\
\text { USA }\end{array}$ & $\begin{array}{l}\text { To examine } \\
\text { associations } \\
\text { between } \\
\text { professional } \\
\text { behaviours of } \\
\text { baccalaureate } \\
\text { nursing students } \\
\text { and student } \\
\text { perceptions of } \\
\text { select factors } \\
\text { within the clinical } \\
\text { learning } \\
\text { environment } \\
\text { using a } \\
\text { conceptual model } \\
\text { developed and } \\
\text { tested by } \\
\text { Manojlovich } \\
\text { (2003). }\end{array}$ & $\begin{array}{l}\text { - Two hundred and forty-three } \\
\text { participants were randomly } \\
\text { recruited . } \\
\text { - A comparative study design used } \\
\text { to test for relationships between } \\
\text { variables in Manojlovich's model } \\
\text { among the student population. }\end{array}$ & $\begin{array}{l}\text { Results revealed: } \\
\text { 1. Direct relationship between student perceptions of structural } \\
\text { empowerment in the clinical learning environment and professional nursing } \\
\text { practice behaviours among students. } \\
\text { 2. Relationship between variables in the model is significantly strengthened } \\
\text { by student perceptions of strong leadership behaviours of clinical faculty. }\end{array}$ & $\begin{array}{l}\text { L - Sampling bias of students who were } \\
\text { more, likely to engage in professional } \\
\text { development activities i.e., a Hawthorne } \\
\text { Effect. } \\
\text { S- Successfully demonstrated } \\
\text { relationship between variables from } \\
\text { Manojlovich's model and that nursing } \\
\text { leadership moderates the strength of the } \\
\text { relationship among other variables. }\end{array}$ \\
\hline $\begin{array}{l}\text { McGowan, } 2006 \\
\text { Who do they think they are? } \\
\text { Undergraduate perceptions of the } \\
\text { definition of supernumerary status }\end{array}$ & $\begin{array}{l}\text { Based on three } \\
\text { research } \\
\text { questions: } \\
\text { How did students }\end{array}$ & $\begin{array}{l}\text { Qualitative study. } \\
10 \text { x Focus group interviews } \\
\text { conducted with a semi-structured } \\
\text { interview schedule between }\end{array}$ & $\begin{array}{l}\text { Nine themes generated that addressed the three research questions } \\
\text { - Definition of supernumerary status: 1. Not counted in staff numbers - } \\
\text { there to learn not to be counted as staff; 2. Lack of student preparation - } \\
\text { students confused about their scope of practice and/or expectations of }\end{array}$ & $\begin{array}{l}\text { L- Focused on UK context questioning } \\
\text { reliability and generalisability of the study. } \\
\text { S - Identifies the nurse manager as } \\
\text { pivotal in providing a friendly and }\end{array}$ \\
\hline
\end{tabular}




\begin{tabular}{|c|c|c|c|c|}
\hline $\begin{array}{l}\text { and how it works in practice. } \\
\text { School of Nursing, University of } \\
\text { Ulster } \\
\text { UK }\end{array}$ & $\begin{array}{l}\text { define } \\
\text { supernumerary } \\
\text { status? } \\
\text { How was it } \\
\text { implemented in } \\
\text { practice? } \\
\text { What effect did it } \\
\text { have on them? }\end{array}$ & $\begin{array}{l}\text { September and October } 2003 \text {. } \\
\text { Convenience sample of } n=60 \\
\text { undergraduate second year } \\
\text { students. First year students } \\
\text { excluded as they hadn't yet been on } \\
\text { placement and third year students } \\
\text { excluded as they were on } \\
\text { placement. }\end{array}$ & $\begin{array}{l}\text { them. } \\
\text { - Implementation of supernumerary status: 3._Leadership style - especially } \\
\text { the nurse manager; 4.Experiences of mentorship - staff seemed } \\
\text { unprepared for their role. Effectiveness depended on the individual. } \\
\text { Frequent reports of poor mentorship; } 5 \text {. An extra pair of hands - students } \\
\text { felt they were allocated basic observations and auxiliary jobs such as bed } \\
\text { making, similar to the apprenticeship model; } 6 \text {.Not allowed to study - } \\
\text { studying on the ward discouraged, viewed with suspicion by nursing staff, } \\
\text { considered as lazy. } \\
\text { - Effect on supernumerary status: 7._Learning was enhanced - when staff } \\
\text { are supportive, enthusiastic and friendly; 8. Feelings of being used - } \\
\text { exhausting workloads and long shifts; } 9 \text {. Reduction in self-confidence - } \\
\text { when student felt their supernumerary status was compromised. }\end{array}$ & supportive learning environment. \\
\hline $\begin{array}{l}\text { O'Driscoll et al., } 2010 \\
\text { Still looking or leadership - Who is } \\
\text { responsible for student nurses' } \\
\text { learning in practice? } \\
\text { Four National Health Service (NHS) } \\
\text { trusts in England } \\
\text { UK }\end{array}$ & $\begin{array}{l}\text { To examine how } \\
\text { widespread } \\
\text { changes in the } \\
\text { NHS workforce } \\
\text { and in higher } \\
\text { education have } \\
\text { impacted on } \\
\text { responsibility for } \\
\text { the leadership of } \\
\text { student nurse } \\
\text { learning in clinical } \\
\text { practice }\end{array}$ & $\begin{array}{l}\text { Mixed method case study (literature } \\
\text { study and stakeholder consultation, } \\
4 x \text { case studies in } 4 \text { NHS trusts in } \\
\text { England using an online version of a } \\
\text { ward learning environment } \\
\text { questionnaire, ethnographic field } \\
\text { work in clinical areas and a curricula } \\
\text { analysis of documents in the } \\
\text { universities associated with each } \\
\text { case study site), between } 2006 \text { and } \\
2007 \\
\text { The sites were a purposeful sample } \\
\text { of universities offering diploma and } \\
\text { degree level nursing programs. }\end{array}$ & $\begin{array}{l}\text { - Thematic content analysis of qualitative data revealed } 7 \text { themes: } \\
\text { negotiating supernumerary status, working in busy clinical areas, } \\
\text { emotions of nursing work, the nature of nursing, learning not teaching, } \\
\text { diversity and multicultural learning environment, leadership and } \\
\text { leadership roles. } \\
\text { - Leadership roles identified as being linked to students' education and } \\
\text { practice learning included: link lecturers, ward managers, practice } \\
\text { development nurses and practice educators, lead nurses/modern } \\
\text { matrons, nurse consultants, clinical nurse specialists, nurse } \\
\text { practitioners mentors [RN Buddies], health care assistants, students } \\
\text { - Student online survey showed overall satisfaction with learning } \\
\text { opportunities in the clinical learning environment (83\%) } \\
\text { - Students' perceptions of particular roles seems less positive (56\% of } \\
\text { student agreed that mentors [RN Buddies] taught regularly) } \\
\text { - Perceptions that workload interfered with learning were significantly } \\
\text { associated with students' experience of stress and anxiety. }\end{array}$ & $\begin{array}{l}\text { S- Mixed method strengthened the study } \\
\text { in that phenomena could be explored from } \\
\text { a variety of viewpoints } \\
S-4 \times \text { sites and a full range of roles which } \\
\text { relate to student learning were sampled } \\
\text { and a large number of responses obtained } \\
\text { add to the generalisability of findings. } \\
L \text { - Non-responded bias might be } \\
\text { considered a threat to the validity of the } \\
\text { study given the } 20 \% \text { response rate to the } \\
\text { online survey ( } n=937 \text { from an identified } \\
\text { population of } 4793 \text { pre-registration nursing } \\
\text { students). }\end{array}$ \\
\hline $\begin{array}{l}\text { Schoenfelder and Valde, } 2009 \\
\text { Creative Practicum Leadership } \\
\text { Experiences in Rural Settings } \\
\text { University of lowa College of } \\
\text { Nursing, } \\
\text { Stewart Memorial Community } \\
\text { Hospital, Lake City and Horn } \\
\text { Memorial Hospital, Ida Grove, lowa. } \\
\text { USA }\end{array}$ & $\begin{array}{l}\text { To prepare } \\
\text { nursing students } \\
\text { for rural heath } \\
\text { settings via the } \\
\text { development, } \\
\text { implementation } \\
\text { and evaluation of } \\
\text { a Rural Clinical } \\
\text { Leadership } \\
\text { Practicum (RCLP) }\end{array}$ & $\begin{array}{l}\text { - RCLP was an onsite elective } \\
\text { clinical course }(135 \mathrm{~h}) \text { for } \\
\text { undergraduate nursing students } \\
\text { piloted in } 2 \times \text { rural health settings. } \\
\text { - These courses provided } \\
\text { foundational leadership content. } \\
\text { - Pre and post the course students } \\
\text { completed the Student Attitudes to } \\
\text { Rural Practice and Life } \\
\text { Questionnaire. } \\
\text { - Students mentored to academic } \\
\text { (remote access) and clinical staff }\end{array}$ & $\begin{array}{l}\text { - Pre- post results from the Student Attitudes to Rural Practice and Life } \\
\text { Questionnaire indicate increasingly positive responses for } 2 \text { items in } \\
\text { Professional Issues and } 4 \text { items in Community and social issues. } \\
\text { - Reflective journals emphasised rural culture, interdisciplinary teamwork } \\
\text { and leadership roles, particularly in relation to the leadership decisions } \\
\text { made by the clinical mentors - the DONs on each site. }\end{array}$ & $\begin{array}{l}\text { L- Small sample for pilot size thus limited } \\
\text { reliability and generalisability of findings. } \\
\text { L- Possible Hawthorne Effect due to } \\
\text { elective nature of course. } \\
\text { S- Development of positive relationships } \\
\text { with clinical mentors (DONs). }\end{array}$ \\
\hline
\end{tabular}




\begin{tabular}{|c|c|c|c|c|}
\hline & & $\begin{array}{l}\text { via an allocated mentor who was } \\
\text { the Director of Nursing (DON) on } \\
\text { each site. } \\
\text { - Students maintained reflective } \\
\text { journals and were evaluated } \\
\text { midway through the course with } \\
\text { their clinical mentors via telephone } \\
\text { conference. }\end{array}$ & & \\
\hline $\begin{array}{l}\text { Thomas and Burk, } 2009 \\
\text { Junior nursing students' experiences } \\
\text { of vertical violence during clinical } \\
\text { rotations. } \\
\text { Junior nursing students in a } \\
\text { university Bachelor of Science } \\
\text { program. } \\
\text { USA }\end{array}$ & $\begin{array}{l}\text { Authors propose } \\
\text { 'vertical violence' } \\
\text { where abused RN } \\
\text { behaviour is } \\
\text { directed towards } \\
\text { students. }\end{array}$ & $\begin{array}{l}\text { Content analysis of stories written by } \\
221 \text { junior nurse students about } \\
\text { incidents of injustice perpetrated by } \\
\text { RNs during their clinical experience } \\
\text { between } 2004 \text { and } 2007 \text {. }\end{array}$ & $\begin{array}{l}\text { Four levels of injustice incidents described } \\
\text { 1. 'We were unwanted and ignored' - failure of RNs to display simple } \\
\text { courtesies, failure to make eye contact, and discouragement. } \\
\text { 2. 'Our assessments were distrusted and disbelieved' - challenging } \\
\text { and belittling behaviours of RNs towards students. } \\
\text { 3. 'We were unfairly blamed' - students used a scapegoats. } \\
\text { 4. 'I was publicly humiliated' - public criticism and humiliation via } \\
\text { yelling, screaming, shouting and chastising. } \\
\text { Students acutely aware of the power differential between themselves and } \\
\text { the RNs }\end{array}$ & $\begin{array}{l}\mathrm{L} \text { - Impact of vertical violence on clinical } \\
\text { learning not examined } \\
\mathrm{S} \text { - Identification of leadership as } \\
\text { important in preventing vertical violence. }\end{array}$ \\
\hline $\begin{array}{l}\text { Zilembo and Monterosso, } 2008 \\
\text { Nursing students' perceptions of } \\
\text { desirable leadership qualities in } \\
\text { nurse preceptors: A descriptive } \\
\text { survey } \\
\text { University nursing school in Western } \\
\text { Australia } \\
\text { Australia }\end{array}$ & $\begin{array}{l}\text { A mix-method } \\
\text { approach to } \\
\text { explore the } \\
\text { leadership } \\
\text { qualities in nurse } \\
\text { preceptors that } \\
\text { are considered } \\
\text { desirable and } \\
\text { contribute to } \\
\text { positive practicum } \\
\text { experiences from } \\
\text { the perspective of } \\
\text { undergraduate } \\
\text { nurses. }\end{array}$ & $\begin{array}{l}\text { - Study in two phases: } \\
\text { - Phase } 1 \text { - development of the } \\
\text { Qualities of Leadership survey } \\
\text { - Phase } 2 \text { - Survey administered to } \\
\text { a group of } 108 \text { nursing students - } \\
\text { purposeful sample. Only } 23 \text { were } \\
\text { returned (a } 21 \% \text { response rate) }\end{array}$ & $\begin{array}{l}\text { - 96\% (22 out of 23) of respondents agreed that leadership was an } \\
\text { important role of the clinical preceptor. } \\
\text { - The highest rated leadership characteristics were clinical competence } \\
\text { and purposefulness (100\%), support, motivation, approachability, } \\
\text { consistency, organisation and effective communication (96\%). } \\
\text { - Analysis of data from open-ended questions uncovered the following } \\
\text { themes re. respondents' definition of clinical leadership: competence and } \\
\text { knowledge; teaching skills; socialisation to the culture of nursing } \\
\text { - Respondents favoured a transformational approach to leadership. }\end{array}$ & $\begin{array}{l}\mathrm{L}-\text { Small sample size thus limited } \\
\text { reliability and generalisability of findings } \\
\mathrm{S}-\text { Trends and themes that emerged offer } \\
\text { direction for future research. } \\
\mathrm{L}-\text { Instrument requires further } \\
\text { development and more rigorous testing to } \\
\text { assess clarity, internal consistency, } \\
\text { validity and reliability. }\end{array}$ \\
\hline
\end{tabular}


students observed and worked alongside staff who role-modelled positive leadership behaviours such as effective interpersonal relationship skills $(n=243)$, there was a strong relationship between student self-efficacy and their perception of professional behaviour and structural empowerment (Livsey, 2009). Student clinical learning experiences were also enhanced in the presence of positive nursing rolemodels (Livsey, 2009); a finding supported in the literature (Henderson et al., 2010; McGowan, 2006). Conversely in situations where students were subjected to vertical violence $(n=221)$, defined as abusive behaviour from a co-worker in a superior position toward a subordinate, they reported feeling unwanted and ignored, distrusted and disbelieved, unfairly blamed, used as scapegoats and publically humiliated (Thomas \& Burk, 2009). Student self-confidence was undermined when they felt their supernumerary status was compromised (McGowan, 2006).

Leadership role-modelling in clinical education is largely dependent on students' immediate supervisor. Analysis of clinical supervision roles provides insight into the leadership practices valued by students during their clinical learning experiences (Allan, Smith, \& Lorentzon, 2008; McGowan, 2006; O'Driscoll et al., 2010; Zilembo \& Monterosso, 2008). Clinical supervisors who are committed, confident and supported by management, and display positive and transformational leadership behaviours are perceived by students to enhance the clinical learning experience (Allan et al., 2008; Zilembo \& Monterosso, 2008). A lack of training and support for clinical supervisor can lead to confusion about their leadership role in clinical learning (McGowan, 2006; O'Driscoll et al., 2010).

Undergraduate leadership programs can also directly impact on undergraduate nursing students when effectively facilitated in the clinical setting (Hendricks, Cope, \& Harris, 2010; Schoenfelder \& Valde, 2009). Elective leadership programs reported by Hendricks et al (2010) and Schoenfelder and Valde (2009) relied on positive role-modelling in the transference of leadership skills and behaviours to students, who reported an increase in their leadership attributes. The program conducted by Hendricks 
et al (2010) consisted of theoretical preparation of students $(n=9)$ before being allocated to a designated nurse leader mentor. Post survey results confirmed statistically significant changes in student's key leadership skills and behaviours such as ability to influence and motivate others, communicate effectively, work collaboratively and team build, develop problem solving and personal skills, overcome obstacles and to serve as agents for positive change.

Similarly, the Rural Clinical Leadership Practicum course developed and evaluated by Schoenfelder and Valde (2009) involved support of participating students through regular reflection and discussion by an on-site clinical team including the Director of Nursing as mentor, and academic team during a rural clinical placement. Ratings on the Student Attitudes to Rural Practice and Life Questionnaire revealed an enhanced awareness of the important leadership decisions made by the clinical teams in relation to the rural culture, teamwork and roles.

Key factors influencing undergraduate clinical learning include the role of the nurse unit/ward manager as the gate-keeper in influencing the learning environment; transformative principals such as empowerment, democracy, vision, affiliation and motivation for change; collaboration and relationship building and; role-modelling. Overall, there was a clear association between positive nursing rolemodels and a supportive learning environment. Where this occurred, students reported perceptions of structural empowerment, empathy and meaningful clinical learning experiences.

\section{Conclusion}

Due to the paucity of research examining the influence of leadership on clinical learning, a narrative synthesis of the literature around nursing and leadership, clinical learning and learning culture was undertaken. The synthesis identified leadership for learning in clinical practice as dependent upon transformative principles, the role of the nurse unit/ward manager, collaboration and relationship 
building and role modelling. As the weight of enquiry around this topic was descriptive, the relationship between leadership and clinical learning culture is yet to be empirically tested and justified. As such the review has raised some suggestions for ongoing investigation aimed at examining the impact of a leadership capacity building intervention that supports clinical learning. 


\section{References}

Allan, H. T., Smith, P. A., \& Lorentzon, M. (2008). Leadership for learning: a literature study of leadership for learning in clinical practice. Journal of Nursing Management, 16(5), 545-555.

Alleyne, J., \& Jumaa, M. O. (2007). Building the capacity for evidence-based clinical nursing leadership: the role of executive co-coaching and group clinical supervision for quality patient services. Journal of Nursing Management, 15(2), 230-243.

Alleyne, J., \& Juuma, M. (2005). Leadership through group clinical supervision. In M. J. M. Jumma (Ed.), Effective Healthcare Leadership (pp. 120-138). Oxford, UK: Blackwell Publishing.

Atsalos, C., O'Brien, L., \& Jackson, D. (2007). Against the odds: experiences of nurse leaders in Clinical Development Units (Nursing) in Australia. Journal of Advanced Nursing, 58(6), 576584.

Bowles, A., \& Bowles, N. (2000). A comparative study of transformational leadership in nursing development units and conventional clinical settings. Journal of Nursing Management, 8(2), 6976.

Brady Germain, P., \& Cummings, G. G. (2010). The influence of nursing leadership on nurse performance: a systematic literature review. Journal of Nursing Management, 18(4), 425-439.

Callaghan, L. (2008). Advanced nursing practice: an idea whose time has come. Journal of Clinical Nursing, 17(2), 205-213.

Casida, J., \& Pinto-Zipp, G. (2008). Leadership-Organisational Culture Relationship in Nursing Units of Acute Care Hospitals. Nursing Economics, 26(1), 7-15.

Centre for Reviews and Dissemination. (2009). Systematic reviews: CRD's guidance for undertaking reviews in health care. York: University of York.

Collins, J. A., \& Fauser, B., C, J, M. (2004). Balancing the strengths of systematic and narrative reviews. Human Reproduction Update, 11(2), 103-104.

Creedy, D., \& Henderson, A. (2009). Final Report: Leading engagement of academic and clinical communities for learning. Strawberry Hills, NSW: Australian Learning and Teaching Council. Document Number)

Cummings, G. G., MacGregor, T., Davey, M., Lee, H., Wong, C. A., Lo, E., et al. (2010). Leadership styles and outcome patterns for the nursing workforce and work environment: A systematic review. International Journal of Nursing Studies, 47(3), 363-385.

Currie, K., Tolson, D., \& Booth, J. (2007). Helping or hindering: the role of nurse managers in the transfer of practice development learning. Journal of Nursing Management, 15(6), 585-594.

Davidson, P. M., Elliott, D., \& Daffurn, K. (2004). Leading contemporary approaches to nursing practice. In S. S. J. Daly, D. Jackson. (Ed.), Nursing Leadership (pp. 285-297). Sydney NSW: Churchill Livingstone.

Davidson, P. M., Elliott, D., \& Daly, J. (2006). Clinical leadership in contemporary clinical practice: implications for nursing in Australia. Journal of Nursing Management, 14(3), 180-187. 
Duffield, C., Roche, M., O'Brien-Pallas, L., Catling-Paull, C., \& King, M. (2009). Staff satisfaction and retention and the role of the Nursing Unit Manager. Collegian, 16(1), 11-17.

Green, B. N., Johnson, C. D., \& Adams, A. (2001). Writing Narrative Literature Reviews for Peerreviewed Journals: Secrets of the Trade. Journal of Sports Chiropractic \& Rehabilitation, 15(1), 5-19.

Heath, P. (2002). National Review of Nursing Education 2002 - Our Duty of Care. Canberra: Commonwealth of Australia.

Henderson, A. (In press). Leadership in clinical education - Embedding learning in everyday practice. Nurse Education Today, In Press, Corrected Proof.

Henderson, A., Twentyman, M., Eaton, E., Creedy, D., Stapleton, P., \& Lloyd, B. (2010). Creating supportive clinical learning environments: an intervention study. Journal of Clinical Nursing, 19(1-2), 177-182.

Hendricks, J. M., Cope, V. C., \& Harris, M. (2010). A leadership program in an undergraduate nursing course in Western Australia: Building leaders in our midst. Nurse Education Today, 30(3), 252257.

Kerfoot, K. (2001). Leading from the inside out. Dermatology Nursing, 13(1), 42-43.

Kouzes, J., \& Posner, B. (1990). Leadership Practices Inventory (LPI): A self-assessment and analysis. San Diego, CA: Pfeiffer \& Co.

Langford, P. H., \& Fitness, J. (2003). Leadership, power and influence. In P. T. T. K. M. O'Driscoll (Ed.), Organisational psychology in Australia and New Zealand (pp. 279-298). Melbourne: Oxford.

Livsey, K. (2009). Structural Empowerment and Professional Nursing Practice Behaviours of Baccalaureate Nursing Students in Clinical Learning Environments. International Journal of Nursing Education Scholarship, 6(1), 1-16.

McGowan, B. (2006). Who do they think they are? Undergraduate perceptions of the definition of supernumerary status and how it works in practice. Journal of Clinical Nursing, 15(9), 10991105.

McMillan, M., \& Conway, J. (2002). Exploring nursing leadership. Australian Journal of Advanced Nursing, 19(4), 5-6.

O'Driscoll, M. F., Allan, H. T., \& Smith, P. A. (2010). Still looking for leadership - Who is responsible for student nurses' learning in practice? Nurse Education Today, 30(3), 212-217.

Pearson, A., \& Borbasi, S. (1996). In praise of tall poppies - Nursing's need for leadership. In J. Anderson (Ed.), Thinking management: Focusing on people. Melbourne: Ausmed Publications.

Rowley, S. D. (2006). The journey of a teaching hospital to become a learning organisation. Australian Health Review, 30(2), 232-240.

Schoenfelder, D. P., \& Valde, J. G. (2009). Creative Practicum Leadership Experiences in Rural Settings. Nurse Educator, 34(1), 38-42. 
Scott-Findlay, S., \& Estabrooks, C. (2006). Mapping the organizational culture research in nursing: a literature review. Journal of Advanced Nursing, 56(5), 498-513.

Senate Community Affairs Committee. (2002). The Patient Profession: Time for Action. Report on the Inquiry into Nursing: Parliament of Australia. Document Number)

Spirig, R., Nicca, D., Voggensperger, J., Unger, M., Werder, V., \& Niepmann, S. (2004). The Advanced Nursing Practice Team as a Model for HIVIAIDS Caregiving in Switzerland. Journal of the Association of Nurses in AIDS care, 15(3), 47-55.

Stapleton, P., Henderson, H., Creedy, D. K., Cooke, M., Patterson, E., Alexander, H., et al. (2007). Boosting morale and improving performance in the nursing setting. Journal of Nursing Management, 15(8), 811-816.

Thomas, S. P., \& Burk, R. (2009). Junior nursing students' experiences of vertical violence during clinical rotations. Nursing Outlook, 57(4), 226-231.

Tregunno, D., Jeffs, L., Hall, L., Baker, R., Doran, D., \& Bassett, S. (2009). On the Ball: Leadership for Patient Safety and Learning in Critical Care. [Article]. Journal of Nursing Administration July/August 2009; 39(7/8):334-339, 39(7/8).

Wallin, L., Rudberg, A., \& Gunningberg, L. (2005). Staff experiences in implementing guidelines for Kangaroo Mother Care--a qualitative study. International Journal of Nursing Studies, 42(1), 6173.

Williamson, T. (2005). Work-based learning: a leadership development example from an action research study of shared governance implementation. Journal of Nursing Management, 13(6), 490-499.

Wong, C. A., \& Cummings, G. G. (2007). The relationship between nursing leadership and patient outcomes: a systematic review. Journal of Nursing Management, 15(5), 508-521.

Zilembo, M., \& Monterosso, L. (2008). Nursing students' perceptions of desirable leadership qualities in nurse preceptors: a descriptive survey. Contemporary Nurse, 27(2), 194-207. 